\title{
In Colombia We Are All Poor
}

\author{
Nelly Ayala Rodrigueza
}

\begin{abstract}
For many, poverty is one of the fundamental problems of Colombia, despite the fact that the economy of the country has been growing and there are efforts of the national government, business, academia, and civil society to contribute to the improvement of this condition. In March 2015, the National Administrative Department of Statistics (DANE, for its Spanish acronym) indicated that in 2014 there was a reduction in the monetary and multidimensional poverty in Colombia. But the truth is that in Colombia we are all poor. We have not been able to take advantage of the visible and invisible wealth we possess. In this sense, this paper provides reflective elements about the fundamental role of three key players in reducing this condition, such as the social sciences from community psychology; the State, with the strengthening of cultural policies; and higher education, viewed from the paradigm of university social responsibility. These reflections are the results of the first phase of a research that is being carried out in an area of the city of Bogota, in which the Catholic University of Colombia, since 2011, has been developing a process of community intervention to contribute to overcoming poverty. This research is a partnership with universities of Brazil and Mexico, with the purpose to develop knowledge and have an impact on public policy in the respective countries.
\end{abstract}

\section{Keywords}

Poverty, community psychology, invisible poverty, invisible wealth

There are riches that are seen, smelled, heard, and felt. There are riches that do not need to be defined to know that they are wealth.

Colombia is located in "the tropics of Northwestern South America and has coasts on the Atlantic and Pacific oceans. It has a territory of 1,141,748 square kilometers included the marine and underwater platforms” (United Nations Development Program-UNDP 2014a: 2). It is a country with a combination of "ethnic and regional specificities involving social practices, world views and cultures that are recognized and protected by the Constitution of 1991" (United Nations Development Program-UNDP 2014a: 1).

It is a multicultural and multilingual country, with white and mestizo population, 87 indigenous ethnic groups, and three distinct groups of Afro-Colombian population and the gypsy community or gypsy people. Sixty-four (64) Amerindian languages besides Bande (language of native islanders of San Andrés, Providencia, and Santa Catalina), Palenquero (of the communities of San Basilio de Palenque), and Romany or Romanes (Rom language) are spoken.

The black or Afro-Colombian population is divided into four groups: Colombian Pacific; native islanders of San Andrés, Providencia, and Santa Catalina; the community of San Basilio de Palenque-which was the first free people of America, having achieved their freedom in 1603; and the urban

aCatholic University of Colombia, Bogota, Colombia

\section{Correspondent Author:}

Nelly Ayala Rodriguez, Transversal 16A No. 45F16 Apto 501. Barrio Palermo. Bogotá, Colombia 
population living in big cities or in the municipal centers. It should be noted that the population of the Pacific Coast maintains its cultural practices from the descendants of African peoples. In this area, there is a presence of 132 Collective Territories of Black Communities occupying a territory of 4,717,269 hectares, representing $4.13 \%$ of the country (United Nations Development Program-UNDP 2014a: 2).

This country has a Nobel Prize in Literature, several Olympians, vallenato music - that has been declared patrimony of humanity, and people everywhere full of joy, optimism, humor, creativity... There are peasants who have cultivated the land with their hands and sweat... and there is much more.

Colombia is a country with much wealth. How much difference, product of diverse world views, traditions, beliefs, and cultural practices! How many ways to take life, to manage conflict! There is a legacy of popular knowledge, stories, and narratives.

In another dimension, Colombia has a great diversity of climate and landscapes, given the presence of six regions: (1) the Andean region, formed by three divisions of the Andes; (2) the Amazon region, considered the lungs of the planet; (3) the Caribbean region, on the northern coast of Colombia; (4) the region of the Orinoco, with huge plains; (5) the pacific region; and (6) the island region. Therefore, Colombia is a country rich in biodiversity.

Colombia, along with Brazil, is the country with the greatest richness in species. These are housed in the Andean region, with about 10,000 of them; in the Amazon region, with 6,800; in the Pacific region, with 7,500; in the Caribbean region, with 3,429; in the region of the Orinoco, with 2,200; and in the island region, with 824 .

A very important place in terms of biodiversity is occupied by the moors, which are not only the home to many unique species in the world, but are the source of $70 \%$ of the freshwater in Colombia. Additionally, the moors are responsible for regulating the water cycle, storing enough atmospheric carbon.
They are also the biological corridors for a great diversity of flora and fauna species. The country has 44.25\% of the South American moors (United Nations Development Program—UNDP 2014a: 2).

Therefore, Colombia is a very rich country. Why is it said to be poor? Because this wealth is invisible to the few people who make the big decisions in the face of what to do with this wealth, how to distribute it, use it, and/or maintain it. It is invisible in a subtle, settled down, and strategic way, because most of us know that Colombia is the richest country in the world at all levels. But at the same time, we have been inundated with the poverty of not knowing what to do with that wealth. Then we have become poor, we have allowed ourselves to be impoverished. We continue making wealth invisible.

Colombia is a social state of law, organized as a unitary, decentralized republic with autonomous territorial units, democratic, participatory, and pluralistic, based on respect for human dignity, work and solidarity of the people who form part of it, and the prevalence of general interest (Constitution of Colombia 1991, Art. 1: 13).

The 1991 Constitution, guarantor of human rights, recognizes among others, the right to life, to liberty, equality before the law, free development of personality, privacy and peace. "Peace is a right and a mandatory duty" (Art. 22: 17). Does it mean that it is a pleasant society for coexistence and for social, political, economic, cultural, and spiritual development of people?

Sadly, everything holds up on paper. The reality contradicts most of the time such an ideal country. Corruption is the number one problem, along with the lack of ethics and transparency, present in most scenarios, not only of public life and governmental instances, but in many areas of national life.

This situation, added to the armed conflict in more than 50 years, which is a result of many dynamics, has caused a strong negative impact on the country's development. It has generated poverty, hopelessness, 
lack of governance, inequity, and affectation on human rights of many people, as well as strengthening the sense of the public. For example, the Human Development Report: Conflict, UNDP Impasse (2003) noted that the main obstacle to human development in Colombia has been this decades-old conflict.

But another difficulty in Colombia is that the building of an empowered civil society with the ability to positively impact and channel development has not been possible. We have made invisible the country's wealth, we have denied it, and have not been able to benefit from it. In other words, we have been impoverished.

In 2013, the National Center of Historical Memory delivered to the President and the country its General Report on Memory and Conflict: "Enough Colombia! Memories of war and dignity, an exemplary contribution to the understanding of the origin and transformations generated by the Colombian armed conflict-Mandates of law justice and peace”. This study located in 1958, the beginning of the conflict that has marked the last 50 years the country where atrocious and systematic crimes against the population generated the violent death of about 180,000 civilians and 40,000 fighters of armed groups, 25,000 enforced disappearances, 27,000 kidnappings, 2,000 massacres, at least 5,000 recruited children, and four million displaced. These are some samples of the enormous direct impact of conflict (United Nations Development Program-UNDP 2014).

But surely there are more victims. The statistics do not reveal the reality. Targeted killings, enforced disappearances, abductions, and small massacres are the facts that have prevailed in the violence of armed conflict; according to the report "Basta ya...!", which states: "Ours is violence with high impact on local and regional level, but with little resonance on the national level. Perhaps this is due to a general feeling of habituation to conflict and to a limited citizen mobilization to put an end to the war". The study was finished in 2012 (United Nations Development
Program-UNDP 2014a: 3).

It is undeniable that all dynamics that outshine the human being are the expression of poverty in its various dimensions. Authors like Boltvinik (2003) stated that "poverty degrades, destroys, moral, social and biologically the greatest cosmic miracle: human life. The existence of poverty is an aberration of social life, a clear sign of the malfunction of society" (Boltvinik 2003: 9).

Along with the signing of the peace agreement between the government and the FARC-EP, the Colombian society faces a great challenge to make peace and reconciliation possible. It is known that the first obstacle to overcome is the process of "naturalization" of poverty and little hope, which has been formed in the people's socio-cognitive schemes. But as has been said, what Colombia needs is to make visible the wealth it possesses.

\section{COLOMBIA, A COUNTRY WITH INVISIBLE AND VISIBLE POVERTY}

There is poverty that can be seen, smelled, heard, and felt. There is poverty that does not need to be defined to know that it is poverty.

It is very sad that there are 200 million poor people in the world or people who are on the verge of poverty. Of these, 1,200 million live on U.S. \$1.25 a day or less. The UNDP Multidimensional Poverty Index shows that nearly 1,500 million people in 91 developing countries live in multidimensional poverty, with deficits in health, education, and living standards. And despite the fact that poverty is declining, nearly 800 million people face the risk of falling back into it because of some crisis or adversity (United Nations Development Program-UNDP 2014b).

In Colombia, even though the economy has been growing and there are efforts from the national government, business, academia, and civil society, to contribute to the improvement of this condition, data 
do not show progress in changing the conditions of the majority.

The National Statistics Department (DANE, for its Spanish acronym) (2016) reported that in 2015, multidimensional poverty in Colombia decreased by 700,000 people. This means that it decreased by 1.7 percentage points. In 2014, it was $21.9 \%$; and in 2015, it became $20.2 \%$. Regarding monetary poverty, when comparing the results of 2015 with the previous year, the percentage of people living in poverty for the national total dropped .7 percentage points, from $28.5 \%$ in 2014 to $27.8 \%$ in 2015 . This would mean that about 171,000 people moved out of poverty between 2014 and 2015.

The value of the monetary poverty line, per household, for the year 2015 was Col. \$894,552. The reduction of extreme poverty at the national level was .2 percentage points; while in 2014 , it was $8.1 \%$ and in 2015, it stood at $7.9 \%$. This means that about 24 thousand people have been lifted out of extreme poverty in Colombia. The value of extreme monetary poverty line, per household, for the year 2015 was Col. $\$ 408,436$ (DANE 2016). By 2015, the Gini coefficient stood at .522 in the national total.

The situation for Bogota, D.C., the capital city of the country, shows a drama that increases day by day. It is the focus of settlement for many people, coming from different regions, who flee their places of origin because of violence, lack of state support, threats from armed groups, and crime, among others. These families swell the misery chains and increase the economic, environmental, and social drama which the capital has itself. This metropolis has a population of 7,878,783 inhabitants (DANE, 2015 census) and the rest on the municipal head with 7,862,277 people.

In 2014, the percentage of people living in poverty in Bogota, D.C. was $10.1 \%$, while in 2013, it was $10.2 \%$, with a reduction of .1 percentage points. Also in 2014, the percentage of people living in extreme poverty in Bogota, D.C., was $1.9 \%$, while in 2013, it was $1.6 \%$, showing an increase of .3 percentage points.
The Gini coefficient recorded for this year was .502, while in 2013, it was .504. It decreased .002 (DANE 2015).

The average per capita income in Bogota, D.C. was Col. \$999,195 (\$316,788 U.S.D.). This means that an average family in Bogota, D.C. consisting of four members had an income of Col. \$3,996,780 (\$1,378,20 U.S.D.). For the year 2013, per capita income had an increase of 4.6\%. In 2014, the poverty line in Bogota, D.C. was Col. \$229,672 (\$79,19 U.S.D.) with an increase of $2.7 \%$ over 2013, when it was Col. \$223,537 (\$77,08 U.S.D.). According to the above, a home in Bogota, D.C. consisting of four people, will be classified as poor if their income is below Col. \$918,688 (\$316,788 U.S.D.) (DANE 2015).

On the other hand, the extreme poverty line which is the minimum per capita cost of a food basket that ensures the caloric basic needs, was Col. \$99,297 (\$34,24 U.S.D.). This means that a four-person household will be classified as extremely poor if their income is below Col. \$397,188 (\$136,96 U.S.D.) (DANE 2015).

Finally, the figures will not change the phenomenon. What counts is to provide solutions for reducing it. So in the following paragraphs, the importance of three key actors is discussed, stressing that if they are put to work in an articulated manner, adding up their expertise, they could greatly contribute to the visibility of the wealth of this country.

\section{ALTERNATIVES TO OVERCOME THE POVERTY STATUS: ALLIANCES, CHALLENGES, AND POSSIBILITIES}

The reduction of poverty is a complex agenda that concerns us all. To address this issue, Kliskberg (2007) suggested the need for joint action by all social actors.

Specifically for Colombia, the author considers the relevant contribution of three scenarios which can cooperate decisively to overcome poverty, through 
networking and in articulated way: (1) the scenario of the social sciences through the disciplinary and professional field of community psychology; (2) the State, through the strengthening of cultural policies; and (3) higher education, through assuming the paradigm of university social responsibility.

\section{Community Psychology}

It is an applied field of psychology, defined as "that which deals with the community and is carried out by the community" (Montero 2004: 31). Among its features, its emphasis lies on the strengths and capabilities of the community, its diversity as active and participatory community action. It is important to stress that "it is one of the few fields of psychology that has had an indigenous development in Latin America” (Wiesenfeld 2014: 7).

This type of psychology emerges as opposed to conventional psychology, i.e., to the dominant paradigms as in the era of the " 60 s, such as positivism. It was born then as "a product and an expression of criticism to the established methods and as a need to produce an effective discipline in the treatment of social problems" (Montero 2004: 35).

In reviewing its origins in Latin America, community psychology arises as an invitation to take a close look at the social contexts and contribute to solving their needs. Amid a positivist psychology, this disciplinary field considered it irrelevant to intervene in the reality of people, under the interests of the researcher, and then be abandoned without them receiving any benefit.

The issue of poverty remains one of its work agendas, such as it was when it appeared in the sixties, demanding a commitment of psychology with the most needy, those who had no voice and no opportunity to participate in building a more equitable and just world.

Hence, Montero (2006) proposed that community psychology aims to promote the development and social transformation of communities. In this regard,
Almeida (2009) stated that community psychology continues to work with the purpose to allow a dignified life for all people through the value of sharing and giving to ourselves the generosity of mutual care.

Consistent with the above, Cintron, Acosta, and Diaz (2009) reported that after 40 years of emergence of community psychology, the change for social justice remains as the fundamental value and mentioned that one reason for this is the fact that despite the socio-historical changes that are taking place in various countries, the gap between the poor and the rich has increased.

With the passage of time, it has been building strategies for working with people and strengthening psychosocial processes. One of these is the so-called "community strengthening", or misnamed by others, "empowerment", a choice of psychosocial intervention that has proved useful to contribute to improving the quality of life of people living under the scourge of poverty.

Lodieu (2009) stated that in community psychology, the actions carried out should be aimed at promoting the control, power, and autonomy of the participants at the personal and collective level. Achieving genuine collective participation implies that all activities undertaken must be designed, crafted, and agreed with the participating groups. And it is then under this approach that community empowerment is achieved as well as that of their members.

As stated by Sawaia (2003), even living in a state of subjection, the human being should be regarded as potentially free, dynamic, and changeable. Hence, Montero (2006) showed how by strengthening the members of a community, high levels of transformation in favor of their living conditions are achieved.

Rappaport (1981), creator of this construct, defined it as the process whereby communities, organizations, and individuals to achieve mastery and 
control of their own lives, which implies the need to build the conditions facilitating this strengthening.

The ethical and political perspective is evident in the conceptions of the term, where what is sought is to privilege horizontal and dialogical relationships, those that recognize the other in their difference and where the presence of conflict is valued as an opportunity.

For Powell (1990), it is the process by which individuals, groups, and communities develop the ability to control their circumstances and achieve the fulfillment of their objectives, thus promoting their quality of life.

As it can be seen, the objective of this process is for change and transformation through self-management. Several authors argue how it is possible for this process to become real.

Swift and Levin (1987) stated that strengthening occurs in four steps: An initial moment where the deficiencies of people in various aspects of their lives are identified or known. This is followed by a stage of clarity or awareness of the deficits they have. This leads to the mobilization of the required power, whether political, social, or economic. And finally, changes in levels of social equity are achieved.

In complementing the previous proposal, Kieffer (1984) proposed three stages in this process. The first one is named "increasing development of the sense of being in relation to the world". In this stage, the person must feel connected to others, never as an isolated individual. The second stage manages to build a critical understanding of the political and social forces that make up our world of life. And the third stage is where the strategies and resources useful for achieving personal or collective social and political roles are designed.

Francescato (1998) stated that the term refers to the development of citizenship and to the process by which the purpose is to revitalize the people "less privileged", helping them "to build on their strengths instead of focusing on their weaknesses", from the perspective of reaching community transformations.
The process of strengthening is a way to materialize the purpose of community psychology which is to guide their work in defense and promotion of life, in recognition of the other and of the power and control they have over their contexts. Likewise, it is a way to contribute to constructing the individual's identity and therefore their citizenship in the perspective of human rights.

Hence, the importance in the process of strengthening is the development of the individual, with the capacity and awareness that he/she is a fundamental social actor who contributes to the social construction of the other and of society.

The Oxford Poverty and Human Development Initiative (OPHI), draws attention to the importance of empowerment in the way that poor people understand their situation, and mentions that it is possible that different types of empowerment are given, all interconnected, with decisive roles in the lives of people. It also highlights the importance that this may have on the measurement of poverty (United Nations Development Program—UNDP 2011).

As stated by OPHI, a conceptual concern about the definitions of "power" is that these generally do not make explicit their assumptions, such as that power will be used for social benefit rather than for socially damaging forms, or that empowered people will need to cooperate to achieve joint goals, and that even empowered persons may be unable to achieve certain goals (United Nations Development Program-UNDP 2011).

In community psychology, it is clear that strengthening has a political function. Its purpose is social transformation, building equitable and humane conditions for coexistence. Overcoming poverty concerns us all. Community psychology will continue to work as it has always done, in the midst of difficulties, by believing in people and dreaming about pleasant societies for coexistence, while the number of "poor" people increases even more, and some governmental agencies believe that the only 
strategy they have to help them is giving them material things. This assistance-oriented approach is permanently questioned since it reinforces the condition of poverty and contributes to its naturalization.

\section{Inclusion of Other Policies Such as Cultural Ones}

One option to overcome poverty is posed by Kliskberg (2007) in affirming the need to develop a kind of policy that simultaneously helps to survive, rehabilitate, train, upgrade, and favor the creation of micro-enterprises, open micro-credits, and develop alternative forms of economy.

Intervention processes or simply support programs for "poor" population are a challenge for governments, because the first thing they should ask themselves is what type of "poor" they are referring to. Is it about the poor that appear on the statistical reports or that who do not appear in these? Or does it refer to both types of poor or to some other conceptions? And then, they should ask themselves: What is the purpose of working with them? If it is not geared to build new possibilities and carry out a real community strengthening process, it would be better to go slowly and with more respect.

A generalized way of community work carried out by the State and some social organizations is through donating groceries, offering scholarships, and engaging participants in some types of programs with a "suggestive" name, where the benefit is rather for these institutions, since they need to demonstrate a wide coverage where the number of participants is what counts. All of this with the aim of maintaining international aid, generates millions of pesos and makes them appear before society as "socially responsible".

Kliskberg (2007) suggested that one option to overcome poverty is to think of a model of integrated development in which culture would have a fundamental weight. Cultural policies with strong public support could be implemented, aimed at large disadvantaged sectors. Culture can be the route to a fully reinforcing inclusion for other paths. What culture can do to return self-esteem to marginalized groups is highly relevant. Humans can lose everything but are carriers of culture. The convening power of culture in the poorest sectors is very important.

But it would seem that governments are not interested to understand, comprehend, and delve deep into the culture of these groups. They are even less interested in promoting the building of citizenship and in the normalization of their living conditions.

In short, venturing into their culture is for UNESCO (United Nations Educational, Scientific, and Cultural Organization) (1996) to understand the way people live together, and how this shapes their thoughts, images, and values. Working on it involves in the first place, contributing to the condition of recognition of these groups, and giving them the status of a social actors with rights and duties, with the ability to dialogue with others, those who have been out of their world, at most, to suggest an adverse and unfavorable imagination. It is essential to delve into the inner world of people, in their imagination, dreams, pains, traumas, and longings. Also, it is important to enter deep into their myths and traditions, their ways of doing and not doing, and their behavior reproduction strategies.

Hence, cultural policies play an important role as a component of the social capital to overcome poverty. This means there is a need to reintegrate this topic at issue - that has been excluded-into an integrated vision of economic, social, and political development, where it has a great role to play along with discussions of various kinds from different areas of society. Development is not directly associated with indicators such as inflation rate or per capita gross domestic product. Fortunately, there is a broader perspective in the discussion on how development-which constitutes the social capital (Kliskberg 2007)—is reached.

This concept emphasizes a series of silent processes that have to do with culture and that thanks 
to the measuring instruments of the social science, it is possible to observe how they influence reality. It consists of four dimensions: (1) confidence in interpersonal relationships; (2) partnership capacity; (3) civic awareness; and (4) prevailing ethical values in society (Kliksberg 2007).

Klisberg (2007: 276) stated that: "Changes in political, economic and social policies require, for their sustainability, cultural correlates... and cultural expressions have the ability to transmit in all their manifestations, in a free and open mode, the agenda of real suffering and claims from the population”.

\section{Higher Education, an Invisible Actor}

Higher education, as a fundamental social actor responsible for the training of future professionals, has a major challenge in interpreting the needs of the context and in knowing how to respond appropriately to them. And if reality is well understood, it will be possible to identify that poverty is one of their work agendas.

In connection with the foregoing, Ayala, Penate, and Hernandez (2014) argued that the construction of knowledge, a purpose of this level of training, can be challenged to answer for the contribution it has made and is currently making to improve the living conditions of populations living in conditions of cultural or economic poverty, as well as for its contribution to building a more supportive, compassionate, and tolerant human being.

Poverty is not only of material type. There are types of poverty that do more damage, such as poverty of ideas, spirit, dreams, and illusions, of creativity, psychological resources, relationships, and skills to face the competitive world. Hence, the invitation for universities is to incorporate into their curricula a comprehensive education based on ethical and cultural values, in the perspective of human rights, so that this "invisible" poverty can be eliminated. Consistent with this, Sen (2000) argued that the solution to poverty must not be only economic since this has political and educational dimensions.

It is well known that education is for individuals, families, and countries in general, and is an accumulation strategy of great value, through which better levels of development can be achieved, thus becoming not only a vehicle of mobilization, but the realization of some of the richest potentials for the human being (Kliksberg 2007). Thus, it is evident that higher education plays a crucial role in explaining the phenomenon comprehensively and in its mission to build grounded strategies that contribute to its resolution.

After almost 20 years that the World Conference on Higher Education took place, it seems that their proposals have been impossible to be carried out. Economic dimensions continue to be imposed on the spiritual and moral ones.

So one of the biggest challenges of the current university is to influence the social evolution and contribute to the construction of social processes with regional identity from the base (Tünnermann Bernheim 2000). De La Red Vega (2009) mentioned that one of the challenges of university is to influence events and social processes in order to favor the sustainable regional identity and well-being of society. In this regard, De La Cruz Ayuso and Sasia Santos (2008) reported that the university has a great responsibility in transforming the structures of injustice and inequality in our societies, which involves putting teaching, research, and social outreach at the service of social justice.

\section{UNIVERSITY SOCIAL RESPONSIBILITY-USR-THE CRITICAL EYE TO LOOK AT HIGHER EDUCATION}

Consistent with the previous approaches is how the movement of the USR (University Social Responsibility) arises. It grants higher education the role of fundamental social actor in the construction of society, or rather, it claims for the way it has played that role. 
The university has a social responsibility—from the dynamic dimension of knowledge, to contribute to the realization and deployment of the person's autonomy and their unlimited pursuit of truth and progress, of their ability to recognize themselves in the other, and of deepening their individuality and self-esteem as a condition for coexistence, respect, and solidarity; to strengthening personal conditions conducive to a better quality of individual decisions, a necessary requirement for a more fruitful and harmonious interaction with others, i.e., for the construction of society (Zuluaga et al. 2009: 43).

And it is under this "ought to be" of the university, that the movement called "University Social Responsibility" arises. It can be defined as a management policy of ethical quality for the university, which seeks to align its four processes (management, teaching, research, and extension), with the university mission, their values and social commitment to contribute to the solution of their problems of exclusion, inequality, and sustainability (Vallaeys, De La Cruz, and Sasia 2009).

It emerges at the beginning of the century, from the questioning that society makes to universities for their contribution to improving the quality of life of social groups. This movement questions the social relevance of the university on their role in contributing to the enhancement of human dignity and the promotion of justice for all, the quality of personal and family life, the protection of nature, and the search for peace.

In the preface to Vallaeys et al. (2009)—one of the few manuals in this field, issued by the Inter-American Development Bank (IADB), as part of its project entitled Initiative on Social Capital, Ethics and Development, created in 2002, Kawabata (2009) stated that awareness of the USR is increasing. Its aim is to promote the comprehensive and analytical reflection of the university on how it should respond to the needs of society through its mission. This means that the USR helps the university to reencounter and reconnect with the social context.

Thus, USR means that the university, in addition to fulfilling the mission for which it was founded, should be increasingly self-reflexive and aware of the time and region where it is located. It should be knowledgeable both of their strengths and weaknesses, their opportunities and threats.

Leon (as cited in Zuluaga et al. 2009: 79) stated that: "University social responsibility means contextualizing knowledge, making it relevant in the regional reality, making it a pillar of development. University social responsibility means regaining the political dimension of the University in its classical conception: as educator of citizens, as guide of the collective humanization project".

The above considerations and assumptions of the USR lead us to consider the importance of constructing knowledge in the classroom, to contribute to overcoming poverty. The university cannot remain oblivious to the problems of the context. While the contribution made is not denied, this is limited, considering the number of universities existing in a particular city, with their respective programs, number of semesters and subjects per year, plus the number of students and all the teaching, research, and extension activities carried out. The question is: Where do all those academic exercises go? Who are the recipients of those wonderful disciplinary constructions? Why is it that the environments of universities do not improve, but on the contrary, they increasingly deteriorate? Is it that due to the burdens involved in accreditation processes, and their respective tasks of writing documents and reports, the real needs of the social groups are being left aside, and the well-written mission statements of the universities are falling on paper?

USR is the paradigm that may contribute to having more equitable and just societies. But it lies in the will of the institutions to welcome it and make it happen.

In this way, some horizons have been shown to combat the scourge of poverty: Firstly, there are 
contributions of community psychology to the strategy of community empowerment. Secondly, considering the inclusion of cultural policies in governmental bodies. And thirdly, from higher education, the approaches of USR draw attention to the need for a university with social relevance.

\section{CONCLUSIONS}

As suggested by Sen (2000), the objective of development is not only to improve in material aspects, but to do so in the areas of life expectancy and culture.

More urgent than any other times, the twenty-first century demands from the university an ethical management, where the most important commitment should be the contribution to integral human development.

Only from the recognition and appreciation of differences, it is possible to construct worthy social contexts for coexistence. And Colombia should take advantage of their differences in all aspects.

Social groups in condition of poverty must begin to denature this condition as a way to start exercising control and power over their lives.

Higher education is a social actor that most times has been absent in the country's process of development.

University social responsibility is the paradigm that is inviting and demanding to the university to establish a relationship with the environment.

\section{References}

Almeida, E. 2009. psicología comunitaria: trabajando con comunidades en las Américas (Community Psychology: Working With Communities in the Americas). San Juan Puerto Rico: Publicaciones Puertorriqueñas.

Ayala, N., B. Hernandez, and W. Penate. 2014. "Representaciones sociales acerca de la responsabilidad social en universidades de América latina” (Social Representations About Social Responsibility in
Universities in Latin America). Doctoral thesis, Universidad de La Laguna España.

Boltvinik, J. 2003. “Conceptos y medición de la pobreza. La necesidad de ampliar la mirada" (Concepts and Measurement of Poverty. The Need to Broaden the View). Papeles de Población 9(38):9-25.

Cintron, F., E. Acosta, and L. Diaz., Eds. 2009. Psicología Comunitaria: Trabajando con comunidades en las Américas (Community Psychology: Working With Communities in the Americas). Hato Rey, Puerto Rico: Publicaciones Puerto Riqueñas, Inc.

Constitution of Colombia. 1991. Actualizada y revisada (Updated and Revised). Bogotá, D.C.: Leyer.

De La Cruz Ayuso, C. and P. Sasia Santos. 2008. "The Responsibility of the University in the Project of Building a Society.” In IESALC. The social responsibility movement of the university: A novel understanding of the university mission. Revista Educación Superior y Sociedad Nueva Época 13(2):17-52.

De La Red Vega, N. 2009. "Necesidades emergentes y responsabilidad social universitaria. Universidad de Alicante” (Emerging Needs and University Social Responsibility. University of Alicante). Valladolid, España. Revista Alternativas. Cuadernos de Trabajo Social 16:65-78.

Departamento Administrativo Nacional de Estadísticas (DANE). 2015. Encuesta Multipropósito. Boletín 2014 (Multipurpose Survey. Newsletter 2014). Retrieved (http:// www.dane.gov.co/files/investigaciones/multi/Boletin_EM_ 2014.pdf).

- 2016. Pobreza multidimensional y monetaria Resultados 2015 (Multidimensional and Monetary Poverty 2015 Results). Retrieved (http://www.dane.gov.co/files/investiga ciones/condiciones_vida/pobreza/cp_pobreza_15.pdf).

Francescato, D. 1998. "Estrategias de capacitación (empowerment) grupal, organizacional y comunitaria en un contexto social cambiante” (Group, Organizational and Community Training Strategies in a Changing Social Context). Pp. 271-280 in Psicología Comunitaria. Fundamentos y Aplicaciones (Community Psychology. Fundamentals and Applications), edited by A. M. González. Madrid: Síntesis.

Gaete, R. 2011. "La responsabilidad social universitaria necesidades sociales emergente y calidad de vida de los ciudadanos propuesta de ámbitos e indicadores” (University Social Responsibility Emerging Social Needs and Quality of Life of Citizens Proposed Areas and Indicators). Universidad complutense de Madrid, Universidad de Antofagasta Chile. Argos 28(54):191-216.

Kawabata. 2009. "Prólogo” (Prologue). In Responsabilidad Social Universitaria. Manual de primeros pasos (University 
Social Responsibility. First Steps Manual), edited by F. Vallaeys, C. De La Cruz, and P. Sasia. Banco Interamericano de Desarrollo-BID-México, D.F.: McGraw Hill.

Kieffer, C. 1984. “Citizen Empowerment: A Developmental Perspective.” Prevention in Human Services 3:9-36.

Kliskberg, B. 2007. El capital social movilizado contra la pobreza: la experiencia del Proyecto de Comunidades Especiales en Puerto Rico (Social Capital Mobilized Against Poverty: The Experience of the Puerto Rico Special Communities Project). 1st ed. Buenos Aires: Consejo Latinoamericano de Ciencias Sociales-CLACSO.

Lodieu, M. T. 2009. En psicología comunitaria: trabajando con comunidades en las Américas (In Community Psychology: Working With Communities in the Americas). San Juan Puerto Rico, Ediciones: Publicaciones Puertorriqueñas.

Montero, M. 2004. Introducción a la Psicología comunitaria. Desarrollo, conceptos y procesos (Introduction to Community Psychology. Development, Concepts and Processes). Buenos Aires: Paidos.

- 2006. Teoría y práctica de la psicología comunitaria: la tensión entre comunidad y sociedad (Theory and Practice of Community Psychology: The Tension Between Community and Society). Buenos Aires: Paidos.

Powell, T. J. 1990. Working With Self-help. Silver Spring, MD: National Association of Social Workers.

Rappaport, J. 1981. "In Praise of Paradox: A Social Policy of Empowerment Over Prevention.” American Journal of Community Psychology 9(1):1-25.

Sawaia Bader, B. 2003. "La comunidad como principio y como entidad cívica: una discussion sobre democracia y felicidad centrada en la familia” (Community as a Principle and as a Civic Entity: A Discussion on Democracy and Family-Centered Happiness). Pp. 9-17 in Fundamentos en humanidades (Fundamentals in Humanities). Chile: Universidad Nacional de San Luis.

Sen, A. 2000. "La pobreza como privación de capacidades" (Poverty as a Deprivation of Capacity). Pp. 114-141 in Desarrollo y libertad (Development and Freedom). Buenos Aires: Planeta.

Swift, C. and G. Levine. 1987. "Empowerment and Emerging Mental Health Technology.” Journal of Primary Prevention 8:71-94.

Tünnermann Bernheim, C. 2000. "Pertinencia social y principios básicos para orientar el diseño de políticas de educación superior” (Social Relevance and Basic Principles to Guide the Design of Higher Education Policies). Educación Superior y Sociedad 11(1 and 2):181-196.

UNESCO (United Nations Educational, Scientific, and Cultural Organization). 1996. "Nuestra diversidad creativa” (Our Creative Diversity). In World Commission on Culture and Development Report. New York: UNESCO.

United Nations Development Program-UNDP. 2003. El conflicto, callejón con salida. Informe Nacional de Desarrollo Humano para Colombia-2003 (The Conflict, Alley With Exit. National Human Development Report for Colombia-2003). Retrieved (http://www.fuac.edu.co/down load/AREAS/13dhu.pdf).

— . 2011. "Las dimensiones faltantes en la medición de la pobreza” (The Missing Dimensions in Measuring Poverty). Revista Latinoamericana Desarrollo Humano. Boletín $75: 1-4$.

- 2014a. Colombia. Objetivos de desarrollo sostenible (Colombia. Sustainable Development Goals). Retrieved (http://www.co.undp.org/content/colombia/es/home/country info.html).

—. 2014b. Informe sobre Desarrollo Humano 2014 (Human Development Report 2014). Retrieved (http://www.undp. org/content/dam/undp/library/corporate/HDR/2014HDR/H DR-2014-Spanish.pdf).

Vallaeys, F., C. De La Cruz, and P. M. Sasia. 2009. Responsabilidad Social Universitaria. Manual de primeros pasos (University Social Responsibility. First Steps Manual). Banco Interamericano de Desarrollo-BID-México, D.F.: McGraw Hill.

Wiesenfeld, E. 2014. "La psicología social comunitaria en América Latina: Consolidación o crisis" (Community Social Psychology in Latin America: Consolidation or Crisis)? Psicoperspectiva 13(2):6-18.

Zuluaga, S., C. Vallejo, D. Cardona, D. Ángel, J. González, C. C. S. Medina, and M. C. Vergara. 2009. RSU Responsabilidad Social Universitaria (RSU University Social Responsibility). Manizales, Colombia: Universidad Autónoma de Manizales.

\section{Bio}

Nelly Ayala Rodriguez, Ph.D., Catholic University of Colombia, Bogota, Colombia; research fields: community psychology, university social responsibility. 